\title{
Morbid Symptoms: What Did Gramsci Really Mean?
}

\author{
Gilbert Achcar \\ sOAs, University of London, London, UK \\ ga3@soas.ac.uk
}

\begin{abstract}
One of Gramsci's most quoted phrases is his 1930 statement in the Prison Notebooks that " $\mathrm{t}$ ] he crisis consists precisely in the fact that the old is dying and the new cannot be born; in this interregnum a great variety of morbid symptoms appear'. This has traditionally been taken to refer to the emergence of fascism against a background of capitalist crisis and failure of anti-capitalist forces. However, a closer examination of the textual and historical context of that sentence indicates that Gramsci was more likely to have been referring to the PCI's ultraleft turn in conjunction with the Comintern's Third Period.
\end{abstract}

\section{Keywords}

Gramsci - morbid symptoms - Italian Communist Party - Comintern - Third Period - fascism - Marx - Lenin

Over the last few years there has been a huge increase in references to Gramsci's famous sentence on 'morbid symptoms' ('fenomeni morbosi' - literally 'morbid phenomena'): 'The crisis consists precisely in the fact that the old is dying and the new cannot be born; in this interregnum a great variety of morbid symptoms appear.'1

1 A. Gramsci, Quaderni del Carcere, vol. 1, Quaderni 1-5 (Turin: Giulio Einaudi editore, 1977), 311. English translation quoted from Selections from the Prison Notebooks of Antonio Gramsci, ed. and trans. Quintin Hoare and Geoffrey Nowell-Smith (London: Lawrence \& Wishart, 1971), 276. In the Italian original, Gramsci says 'fenomeni morbosi', literally 'morbid phenomena'. 
The present author contributed to this surge by borrowing the phrase 'morbid symptoms' for the title of a 2016 book on the counter-revolutionary phase that followed the 2011 Arab Spring, and by quoting the whole sentence as epigraph to the book. ${ }^{2}$ The increase in references to Gramsci's saying has been such that it is highly probable that most of those who use it have hardly read anything more from him.

The obvious reason for this reflection being added to the canon of common Gramscian clichés - such as, for example, Gramsci's other well-known reflection about the pessimism of the intellect and the optimism of the will - is that it provides a clue to the recent emergence on the global scale of various phenomena that are 'morbid' from a progressive perspective. There has been a spectacular surge of far-right movements worldwide over the last few years, including governments run or co-run by political forces that reproduce some of the key ideological tenets of fascism in countries as varied as Brazil, Hungary, India, Italy, the Philippines, Russia and the United States.

The dominant interpretation of Gramsci's saying is thus predicated upon the belief that, by 'morbid symptoms', he did mean fascism. But was this really what Gramsci meant by this phrase when he wrote it? Or did he mean something very different from the way most people instinctively interpret his saying today in the light of current global conditions? To verify this matter, the quotation needs to be reinserted in the text in which it appeared and the whole text to be replaced in its historical context. It will then emerge that there are in fact strong reasons to believe that Gramsci meant something quite different from the interpretation of his saying that is commonly held at present.

\section{Deciphering Gramsci's Text in Historical Context}

The text to which Gramsci's famous sentence belongs is an entry of his Prison Notebooks, in Notebook 3 of the year 1930. ${ }^{3}$ What was the historical background then? The Wall Street Crash of October 1929 had ushered in the Great Depression, the most severe crisis of capitalism prior to the ongoing crisis provoked by the Covid-19 pandemic, giving a strong impetus to the rise of a European far right already emboldened by the fascist power grab in Italy in 1922. In the world communist movement, the ultraleft turn that began in 1928

2 G. Achcar, Morbid Symptoms: Relapse in the Arab Uprising (Stanford, CA: Stanford University Press, and London: Saqi Books, 2016).

3 Gramsci, Quaderni del Carcere, Q3, §34, pp. 311-12; Selections from the Prison Notebooks, pp. 275-6. In what follows, quotes from this entry will not be referenced. 
with the Third Period of the Communist International (Comintern) had intensified, along with the termination of the New Economic Policy (NEP) and the beginning of rural collectivisation in the Soviet Union in November 1929. ${ }^{4}$

Most importantly for Gramsci, the Italian Communist Party (PCI), under pressure from the Comintern's leadership and after much hesitation and reluctance, had followed suit in March 1930 by adopting an ultraleft perspective predicated on the impending collapse of fascism and the imminence of a proletarian revolution in Italy, thus discarding as inadequate the democratic perspective in the fight against Mussolini's rule.

In September 1929, [Palmiro] Togliatti's position within the party seemed ... distinctly shaky. It was without question to defend his position that he decisively embraced the extreme interpretation of Third Period theory. He maintained that 'the elements of an acute revolutionary crisis' were in the process of ripening in Italy; he extended the theory of 'social fascism' to Italian social democracy and the 'Giustizia e Libertà' movement; and he rejected the hypothesis of an intermediate phase between the collapse of fascism and the proletarian revolution. ... Alfonso Leonetti, an ex-journalist from the Turin Ordine Nuovo who had been very close to Gramsci, and two other leaders with longstanding experience of trade union work, Pietro Tresso and Paolo Ravazzoli, opposed [the new line] vigorously, fiercely attacking Togliatti for having accepted such a line. ${ }^{5}$

In June, the 'Three', already excluded from the leading organs, were expelled from the party for having made contact with the international Trotskyist opposition ... However, the 'svolta' [the turn] was not imposed without significant resistance. Umberto Terracini and Antonio Gramsci, who were kept abreast of the major lines of debate within the party, showed their opposition from their prison cells both to the party's treatment of the opposition and to a political stance which they considered abstract and wanting in any prospects. Both considered it a mistake to rule out a phase of democratic transition after the fall of fascism, and they believed the equation of social democracy and fascism unjustified. Gramsci did not hesitate to display his disagreement to comrades who were in gail with him. ${ }^{6}$

4 See M. Worley (ed.), In Search of Revolution: International Communist Parties in the Third Period (London: I.B. Tauris, 2004).

5 A. Agosti, 'The Italian Communist Party and the Third Period', in Worley, In Search of Revolution $97-8$.

6 Ibid., 99. 
Gramsci's opposition to the ultraleft turn and its political and organisational consequences is well-known. ${ }^{7}$ Let us now decipher the language of the Prison Notebooks, which Gramsci had to encrypt for obvious censorship reasons, especially when dealing with Italian politics of the day and Communist Party debates. His 1930 entry must evidently be read in the light of the historical circumstances described above. It starts enigmatically as follows: "The aspect of the modern crisis which is bemoaned as a "wave of materialism" is related to what is called the "crisis of authority"'

If we relate this puzzling reference to a 'wave of materialism' to Gramsci's forecast later in the same entry of an 'unprecedented expansion of historical materialism', it appears clearly enough that he was referring, not to some new improbable trend in popular culture, but to the ongoing expansion of the communist movement (the official political holder of 'materialism' and especially 'historical materialism', i.e. Marxism) in the context of the polarisation between radical left and radical right that developed during the interwar crisis. The expansion of communism was naturally linked to a crisis of capitalist legitimation, namely a weakening of popular consent as part of capitalist hegemony: 'what is called the "crisis of authority".

Gramsci goes on:

If the ruling class has lost its consensus, i.e. is no longer 'leading' but only 'dominant', exercising coercive force alone, this means precisely that the great masses have become detached from their traditional ideologies, and no longer believe what they used to believe previously, etc.

Referring here apparently, albeit indirectly, to the PCI's assessment ('if') of the loss of popular support by capitalism in general and the fascists in particular, Gramsci deploys his well-known categories of leadership (which he also called hegemony), based primarily on consent, as opposed to domination based on coercion alone. ${ }^{8}$ If leadership has been replaced with domination, in the Gramscian sense of both terms, this naturally implies that 'the great masses have become detached from their traditional ideologies'.

7 For concurring albeit different takes on Gramsci's reaction on this issue, see G. Fiori, Antonio Gramsci: Life of a Revolutionary, trans. Tom Nairn (London: New Left Books, 1970; London: Verso, 199o); A. Leonetti, Note su Gramsci (Urbino: Argalia, 1970); P. Spriano, Antonio Gramsci and the Party: The Prison Years, trans. John Fraser (London: Lawrence \& Wishart, 1979).

8 A more accurate and literal translation would give in the above quote: 'the dominant class has lost the consent' (la classe dominante ha perduto il consenso in the original) instead of 'the ruling class has lost its consensus'. 
However, it does not mean by the same token that the situation has become ripe for a communist-led revolution. To come true this last development would require political conditions - the adoption by the great masses of the Communists' political perspective - that were not yet met in Gramsci's view. His next sentence summarises his assessment of the situation and what he sees as the consequence of that historical deadlock: "The crisis consists precisely in the fact that the old is dying but the new cannot be born; in this interregnum a great variety of morbid symptoms appear.'

A comment on Gramsci's use of the medical metaphor 'morbid' is in order here, taking into consideration the historical context explained above. Standing in opposition to the ultraleft turn of the PCI, it is highly probable that Gramsci had in mind Lenin's characterisation of 'left-wing' communism (or 'Leftism') as an 'infantile disorder.' ${ }^{9}$ Thus, rather than referring to the surge of fascism in the context of the capitalist crisis and the gap between the depth of the crisis and the weakness of the working-class forces called on to replace capitalism with socialism (the 'historically normal solution' that is mentioned below), it is most likely that 'morbid symptoms' actually referred to the ultraleft symptoms that emerged against this backdrop.

And yet Gramsci did not want to sound defeatist. Just because ultraleft optimism is not relevant does not mean that the capitalist order will necessarily prevail, as he explained right after:

The problem is the following: can a rift between popular masses and ruling ideologies as serious as that which emerged after the war be 'cured' by the simple exercise of force, preventing the new ideologies from imposing themselves? Will the interregnum, the crisis whose historically normal solution is blocked in this way, necessarily be resolved in favour of a restoration of the old?

In unencrypted words, this would mean: can the postwar popular disaffection with the dominant capitalist ideology be overcome solely by the coercive means of fascism, so that communism would be successfully prevented from taking over? In that case, would the present fascist transitional period necessarily lead to a restoration of pre-fascist traditional bourgeois rule? Gramsci replied to the question that he had formulated:

9 V. Lenin, 'Left-Wing' Communism: An Infantile Disorder (1920), first published in English under the literal translation of The Infantile Sickness of 'Leftism' in Communism. 
Given the character of the ideologies, that can be ruled out - yet not in an absolute sense. Meanwhile physical depression will lead in the long run to a widespread scepticism, and a new 'arrangement' ['combinazione' in the original] will be found - in which, for example, Catholicism will even more become simply Jesuitism, etc.

In unencrypted words, this probably means to say: the character of the capitalist ideology and its fascist variant in Italy are such that a simple return to pre-fascist traditional bourgeois rule can be ruled out. Instead of such a straightforward restoration, the economic depression will lead fascism in the long run to dilute its own principles even more and adapt its type of rule to traditional bourgeois rule, much as Jesuitism was a dilution of stricter Catholic ethics. And here comes Gramsci's own positive perspective: 'From this too, one may conclude that highly favourable conditions are being created for an unprecedented expansion of historical materialism.'

In other words: in the context of the ongoing economic crisis, the weakening of fascism - the variant of capitalist ideology that captured growing mass discontent and deflected it from opposition to capitalism - should create objective conditions that are highly favourable for an unprecedented expansion of communism. This last sentence may sound very 'optimistic' to contemporary ears. However, compared with the Comintern's and the PCI's ultraleft optimism in 1930, it sounded rather like a quite sober and cautious assessment.

\section{Gramsci's 'Morbid Symptoms' in the 21st Century}

Does the above explanation of what Gramsci most probably meant with his oft-quoted sentence imply that the present spike in the frequency of references to that same sentence is but an instance of widespread misuse of a quote, due to misinterpretation? Such is actually not the case.

Gramsci was writing at a time when fascism had already been eight years in power in his country and a time when the communist movement was expanding from a level of strength that was already far above that of any form of organised radical left in our time. He misjudged the period, focusing solely on his country and the alleged crisis of fascism there, as perceived through his party's assessment. He did not, and probably could not from his prison, realise that Third Period Communism was a far more serious morbid condition than the 'infantile disorder' that Lenin had criticised in 1920, that it was not a manifestation of political impatience by young revolutionaries, but an ultra-sectarian orientation that served to consolidate the Stalinist bureaucratic control of 
the Soviet Union and of the Comintern, and a historical development whose consequences were instrumental in allowing the far right to triumph in Europe - most fatally in Germany.

However, the central idea in Gramsci's famous sentence belongs to the appraisal of any transitional phase during which an old order is already dying, but a radically different new one is not yet able to be born - an appraisal that was key to Marx's analysis of Bonapartism. Gramsci and his fellow Italian Marxists could not fail to find in it a clue to their own analysis of fascism, which they saw indeed as a degenerate form of Bonapartism. In Marx's words,

The Empire, with the coup d'état for its certificate of birth, universal suffrage for its sanction, and the sword for its sceptre, professed to rest upon the peasantry, the large mass of producers not directly involved in the struggle of capital and labour. It professed to save the working class by breaking down Parliamentarism, and, with it, the undisguised subserviency of Government to the propertied classes. It professed to save the propertied classes by upholding their economic supremacy over the working class; and, finally, it professed to unite all classes by reviving for all the chimera of national glory. In reality, it was the only form of government possible at a time when the bourgeoisie had already lost, and the working class had not yet acquired, the faculty of ruling the nation. ${ }^{10}$

The same type of historical deadlock between the 'already' incapable bourgeois rule and the 'not yet' capable working-class rule, which produced Bonapartism, can also most naturally generate revolutionary impatience on the part of radical activists acting on behalf of the workers and seeking shortcuts to the revolution. This had already happened on a large scale during the revolutionary situation that started unfolding soon after the outbreak of the First World War in several European countries, which became thus confronted with a situation in which 'the bourgeoisie had already lost ... the faculty of ruling the nation' but 'the working class had not yet acquired' this same faculty. ${ }^{11}$

The gap between 'already' incapable bourgeois rule and 'not yet' capable workers' rule likewise constitutes a fertile ground for the rise of another serious

10 K. Marx, The Civil War in France (1871), in Karl Marx Frederick Engels Collected Works, vol. 22 (London: Lawrence \& Wishart, 1986), 330; emphasis added.

11 Lenin's famous comment on objective and subjective conditions during a revolutionary situation - V. Lenin, 'The Collapse of the Second International', in Collected Works, vol. 21 (Moscow: Progress Publishers, 1964), 213-14 - informed his critique of 'left-wing communism' a few years later. 
disorder: not of socialist orientation, but of bourgeois politics in the form of the far right. The surge of the latter typically happens when traditional bourgeois rule starts losing legitimacy (consent, hegemony) against a backdrop of socio-economic crisis while the anti-capitalist left is not yet strong enough to take the lead among the people (the nation). As with the 'infantile disorder' of radical left politics, the far-right disease of bourgeois politics can take the shape of mass movements, but also engender terrorist fringe activities when the former fail to arise.

Our present global conditions are, to be sure, very different from those of 1930. The effect of the global economic crisis has not yet been as acute and dramatic as that of the Great Depression of the 1930s. Yet it comes on top of decades of neoliberal unravelling of the post-1945 'social contract' upon which liberal capitalist hegemony was established. Unfolding since the 1980 os at a time of deep crisis of the left globally in what turned out to be the last decade of the Soviet Union, the 'fatherland of socialism' of a bygone age, the neoliberal destabilisation and precarisation of the global socio-economic conditions nurtured a global retrenchment behind identity markers (religion, race, nation) along with a sharp drift to the right. Together, these developments led to what this author called, in the aftermath of 11 September 2001, a 'clash of barbarisms $^{\prime 2}$ - the reality behind what Samuel Huntington misdiagnosed superficially as a 'clash of civilizations' because it had the appearance of a cultural antagonism along global civilisational fault lines, whereas it was in fact a clash between the worst tendencies emerging within each cultural sphere.

Nonetheless, the emergence of global new left currents, particularly among the youth, is manifest enough to allow us to identify a global left-right polarisation of politics fostered by the economic crisis against a backdrop of deepening crisis of the old order in all its different political forms, from democratic to despotic. We have re-entered a situation where the old is 'already' dying and the new can 'not yet' be born. The hitherto weakness and fragility of the forces of progressive change have meant that the accelerating crisis of the socio-economic and political conditions of global capitalism has until now mostly benefitted the rise of the far right around the globe. It is hence on the far right of the political spectrum that we are witnessing at present the most spectacular 'morbid symptoms' produced by the degeneration of capitalist politics.

12 G. Achcar, The Clash of Barbarisms: The Making of the New World Disorder, 2nd ed. (Boulder, CO: Paradigm Publishers, and London: Saqi Books, 20o6). My preface to the recent third French edition of this book is available in English on the Jacobin website, at https://www. jacobinmag.com/2017/o6/isis-terrorism-trump-xenophobia-iraq-war-syria. 
Applying Gramsci's sentence to this reality is therefore legitimate, even if it is historically inaccurate.

\section{Acknowledgements}

A previous version of this article was published in the International Socialist Review 108 (March 2018). It is based on a presentation given at a conference held in Cagliari, Sardinia, on 27-28 April 2017, organised by the Gramsci Institute, the University of Cagliari and Sassari, and the municipality of Cagliari, on the occasion of the 8oth anniversary of Antonio Gramsci's death. 